Аналіз сутності етичної компетентності майбутньго перекладача

ЛАШКУЛ В. А. , кандидат педагогічних наук, асистент,

Національний університет біоресурсів і природокористування України

E-mail:Valery776@bigmir.net

ORCID 0000-0002-3709-3306

ТИмОФєєВ В. А. , викладач першої категорії,

Київський державний коледж туризму та готельного господарства

E-mail: uebersetzer4@gmail.com

ORCID 0000-0001-6977-6454

Анотація. У статті автори розкривають сутність феномену етичної компетентності майбутнього перекладача, оскільки виклики часу вимагають утвердження нових концептуальних тенденцій, пов'язаних з гуманізацією та гуманітаризацією освіти. Особливої актуальності ці тенденції набувають у гуманітарно-педагогічній освіті, зокрема у фрілології. Сучасна вища освіта не повинна ставити собі за мету лише фрормування необхідного обсягу професійних знань, умінь та навичок у майбутнього фрілолога-перекладача. Сьогодення вимагає, щоб інструментальна сфрера особистості випускника фрілологічного факультету тісно поєднувалася з розвитком мотиваційно-ціннісної сфрери, морально-етичними якостями, що в синтезі забезпечує грунтовну профресійноетичну підготовку фрахівця.

Ключові слова: професія, переклад, компетенція, компетентність, фрілологія, етика, мораль, компетентнісний підхід, освіта.

\section{Актуальність дослідження.} Важливу роль у формуванні моральної культури людини й суспільства має відігравати етичне просвітництво, що несе знання про моральні цінності, дає розуміння морального виміру поведінки особистості, дій соціальних суб'єктів, життя суспільства.

Освіта в Україні вважається одним із основних компонентів загальнолюдських цінностей, метою якої $\epsilon$ «всебічний розвиток людини як особистості та найвищої цінності суспільства, розвиток ії талантів, розумових i фрізичних здібностей, виховання високих моральних якостей, формування громадян, здатних до свідомого суспільного вибору» [10]. Тобто зміст державної української освіти передбачає всебічний та гармонійний розвиток людини як $у$ патріотичному, трудовому, національному, правовому, так і в моральному та духовному аспектах. Отже, сучасна система освіти в Україні передбачає підготовку спеціалістів 3 якісною професійною підготовкою та високими моральнодуховними рисами.

Професійний переклад в Україні знаходиться зараз у процесі свого становлення. Не дивлячись на те, що існує багато перекладеної літератури, читачеві нерідко самому доводиться домислювати, що означає те чи інше речення-калька або українізоване слово з іноземною вимовою.

Переклад потрібно довіряти висококваліфрікованим спеціалістам, які не лише володіють професійною компетентністю, але й етичною, тобто вміють виконувати переклад з огляду на моральний аспект цього виду діяльності.

3 цього положення витікає напрям розв'язання проблеми підготовка перекладачівпрофесіоналів з високими моральними якостями та усвідомленням

HUMANITARIAN STUDIOS: PEDAGOGICS, PSYCHOLOGY, PHILOSOPHY Vol 12(4) 2021

(C) Лашкул В. А. , Тимофєєв В. А. 
відповідальності за результати своєї діяльності.

\section{Аналіз досліджень і}

публікацій. Важливим кроком в дослідженні професійного перекладу як духовно-творчої діяльності, яка має свої специфічні особливості $€$ роботи багатьох науковців.

Зокрема, у своїх роботах Н. М. Петренко [15] «Вступ до перекладознавства» окреслив шляхи вивчення перекладу на діяльнісній основі.

Про зв'язок перекладу 3 духовною діяльністю писалитакі перекладознавці як А. Ф. Ширяєв [20]. Автор вважає, що мовленнєва діяльність виступає діяльністю у сфері духовного виробництва. А письмовий (передусім художній) переклад, за визначенням А. В. Федорова [18], являє собою духовну діяльність. перекладацької діяльності як суспільної діяльності «однієї з форм суспільної практики, що реалізується у двомовній комунікації» $[5$, с. 10$]$, і визначає переклад як духовнопрактичну діяльність, яка пов'язана 3 комунікативною діяльністю.

Концепцію про суспільне призначення перекладацької діяльності поділяють і розвивають перекладознавці Л. К. Латишев та А. Л. Семенов [12].

Переклад визнається авторами як суспільно-детерміноване явище, діяльність, мотив якого - традиційне суспільне замовлення на переклад прописаний перекладачеві суспільством.

\section{Мета дослідження}

проаналізувати сутність феномену етичної компетентності майбутнього перекладача, оскільки успішність діяльності майбутнього фрахівця перекладознавця, становлення його як профресіонала прямо залежить від рівня його професійно-етичної підготовленості. Зважаючи на це, реалії сьогодення

вимагають активізації педагогічних досл.іджень, спрямованих на вивчення процесів формування та розвитку етичної компетентності у майбутніх перекладачів.

Результати. Діяльність можна трактувати як «Специфічну людську форму активного ставлення до оточуючого світу, зміст якої складає його цілеспрямована зміна та перетворення в інтересах людей». Будь-яка діяльність включає мету, засіб, результат і сам процес діяльності, і, відповідно, невід'ємною характеристикою діяльності $\epsilon$ ії усвідомлення. Якщо основою діяльності $€$ свідомо формована мета, то основа самої мети лежить поза діяльністю, у сорері людської моралі.

Життя сучасної людини, як правило, розподіляється на загальну життєдіяльність та спеціалізовані види діяльності. До останніх відносять різноманітні види професійної та любительської діяльності [1, с. 440]. Розглянемо сутність профресійної діяльності.

Профресія - це рід трудової діяльності, який вимагає певної підготовки і $€$ основним джерелом існування. «Професійна діяльність $€$ окремим підвидом трудової діяльності, відмінна риса якої в тому, що це стійкий рід діяльності людини, який вимагає від неї певної кваліфікації (сукупності знань, умінь та навичок) і $\epsilon$ для неї джерелом існування, що й стає для людини основним спонукаючим мотивом самої діяльності». Серед професійних видів діяльності виділяють перекладацьку.

Слово «переклад» належить до числа загальновідомих та загальноприйнятих, але має два термінологічних значення на позначення особливого виду людської діяльності та її результатів. [6, с. 5] Уточнимо терміни «перекладацька діяльність» та «професійна перекладацька 
діяльність», які часто вживаються як рівнозначні.

При тлумаченні перекладу 3 позицій лінгвістичної теорії «як міжмовного перетворення або трансформації тексту однією мовою у текст іншою мовою» [4, с. 6]. Перекладацькій діяльності надається статус особливого виду мовленнєвої діяльності, що полягає у тлумаченні та передачі отримуваної інфрормації .

Профресійний переклад вимагає спеціальної підготовки не лише як особливий вид мовленнєво мисленнєвої діяльності, але й як складний, різнобічний та поліфункціональний вид міжкультурної комунікації, націленої на виявлення та тлумачення смислового змісту письмових та усних текстів, що створюються в одній культурі, й адаптацію їхнього змісту до сприйняття представниками іншої культури.

3 точки зору професійної педагогіки перекладацьку діяльність можна охарактеризувати як роботу 3 пошуку, постановки та розв'язання перекладацьких задач та втілення результатів у міжкультурній комунікації в письмовій або усній формі.

Профресійно-перекладацька діяльність спрямована на вироблення певного текстового продукту в усній або письмовій фрормі, за адекватність інформації якого перекладача несе повну відповідальність.

Перекладач у своїй діяльності підпорядковує власні інтереси суспільним, в чому виявляється морально-етична фрункція профресії перекладача.

Український дослідник І. А. Зязюн зазначає, що професійна компетентність - це підвалина профресійної майстерності, яка $€$ «комплексом властивостей особистості, що забезпечує високий рівень самоорганізації професійної діяльності» [9]. «Опанування компетентністю створює основу для розвитку профресіоналізму (продуктивних способів дій) і майстерності (гнучкості, пластичності, адаптивності до нових ситуацій)».

Суть професіоналізму складає органічний сплав високого рівня виконання професійних обов'язків 3 певними особистісними якостями. Профресіоналізм - це висока готовність до виконання завдань професійної діяльності. Деякі дослідники Ягупов В. В. [21], Петренко Н. М. [16], характеризують профессіоналізм як наявність у спеціаліста знань, умінь та навичок, що дозволяють йому виконувати свою діяльність на рівні сучасних вимог науки та техніки. У визначенні професіоналізму підкреслюється професійна компетентність, моральність, ініціатива й майстерність як стійка властивість особистості та діяльності, а також як здатність до саморозвитку й самокорекції.

Профресійна майстерність - це «високий і постійно удосконалюваний ступінь оволодіння конкретними видами діяльності». Класик педагогічної думки В. А. Сухомлинський [17], визначає професійну майстерність як володіння професійними знаннями, вміннями та навичками, які дозволяють спеціалісту успішно досліджувати робочу ситуацію (об'єкт та умови діяльності), фрормулювати професійні завдання виходячи із цієї ситуації, успішно розв'язувати їх відповідно до цілей, що стоять перед виробництвом.

Особливу увагу такі дослідники як Балл Г. О. [2], Петренко Н. М. [16] та Чужакин А. П., Палажченко П. Р. [19], звертають на морально-етичний компонент професійної майстерності перекладача. Скромність, тактовність, вміння триматися, зберігати таємницю - обов'язкова частина профресійної поведінки перекладача. Таким чином, крім спеціальних знань, умінь та навичок, формування професійної майстерності перекладача передбачає

HUMANITARIAN STUDIOS: PEDAGOGICS, PSYCHOLOGY, PHILOSOPHY Vol 12(4) 2021

(C) Лашкул В. А. , Тимофєєв В. А. 
розвиток особливого типу особистості, який відповідатиме морально-етичним особливостям цієї професії.

Портрет типового перекладачапрофесіонала накреслено перекладознавцем Г. Е. Мірамом: «Інтелігентний, бездоганно ввічливий і коректний, 3 голосом гучним і приємного тону, всебічно освічений, 3 почуттям власної гідності та усвідомленням значущості своєї професії» [14 с. 331].

Профресійну діяльність перекладача слід розглядати в аспекті компетентнісного підходу, котрий визначається як сукупність конкретних знань і навичок, здібностей, готовності до пізнання, оцінки підготовленості певного освітньо-кваліфікаційного рівня до професійної діяльності на основі наявності визначених компетентностей .

Науковці виділяють три складові компетентнісного підходу: компетенцію, компетентність, профресійну компетентність.

Терміни «компетенція» та «компетентність» утворені від латинського competentia, що означає «узгодженість частин» [8, с. 167]. В українську мову поняття «компетенція» увійшло у двох значеннях:

1. Коло повноважень якогось органу чи посадової особи.

2. Проблема, про яку в когонебудь багато інформації, що дає йому змогу фрахово ії розв'язати [11 c. 373].

Отже, компетентною називають людину, яка добре обізнана з певної галузі, має знання, здібності та досвід, що дозволяють їй обґрунтовано судити про цю галузь та ефективно діяти в ній.

Терміни «компетенція» та «компетентність» часто згадуються у програмних документах як мета навчання і вживаються як синонімічні. Проте між ними є суттєва різниця.

Компетенцію належить розуміти як наперед задані вимоги до освітньої підготовки, сукупності знань, способів діяльності, кола повноважень, досвіду, якостей особистості; як складну інтегровану, багатоаспектну якість особистості. Компетентність - це уже існуюча якість, реальна демонстрація набутих знань і відповідних умінь та навичок людини як суб'єкта профресійної діяльності, володіння нею відповідними компетенціями і здатність застосовувати їх у відповідних профресійних ситуаціях. Відповідно, формування компетенцій відбувається засобами змісту освіти. Результатом учіння $€$ компетентність.

Профресійна компетентність виступає критерієм якості підготовки випускників вищого навчального закладу. У той же час професійною компетентністю називають індивідуально-психологічне утворення, яке включає досвід, знання, вміння, навички, особистісні якості якими повинен володіти спеціаліст та психологічну готовність.

Профресійна компетентність перекладача включає сукупність профресійно важливих якостей які зумовлюють готовність до перекладацької діяльності. В освітньокваліфрікаційній характеристиці перекладача зазначено, що професійний перекладач має знати: мови, що використовуються під час перекладу; методики перекладу; чинну систему координації перекладів; термінологію 3 певної тематики мовами, що використовуються для перекладу; повинен вміти працювати зі словниками, термінологічними стандартами, збірниками, довідниками; знати основи наукового і літературного редагування; граматику і стилістику мови. А що ж стосується етичного компоненту у перекладацькій діяльності.

Американський науковець Дж. Баумен [22] зазначає, що майже будь-яке рішення, котре приймає спеціаліст, має етичний характер.

HUMANITARIAN STUDIOS: PEDAGOGICS, PSYCHOLOGY, PHILOSOPHY Vol 12(4) 2021

(C) Лашкул В. А. , Тимофєєв В. А. 
Наприклад, вибір шляху розв'язання проблеми включає раціональноморальне судження. Тому, для того щоб бути профресійно компетентним, спеціаліст зобов'язаний володіти також і етичною компетентністю, щоби приносити користь людям, для яких він працює.

Звідси ми робимо висновок про тенденцію протиставляти етичну компетентність професійній. Наприклад, перекладач може бути висококваліфікованим професіоналом, але гордовитою, замкненою, нечесною особистістю. Або навпаки, низький професіоналізм сполучається В особистості спеціаліста з високими моральними якостями. Завданням професійної підготовки перекладача $є$ гармонійне формування обох компетентностей.

у статті американських дослідників Дж. Чітхема та Дж. Чіверса «етична компетентність визначається як володіння відповідними особистими та професійними цінностями, а також вміння ефективно їх застосовувати у профресійній діяльності. Якщо спеціаліст порушує моральні цінності, обов'язок та відповідальність, то він виявляє етичну некомпетентність і нездатність виконувати суспільне призначення своєї профресії» [24].

Деякі науковці зазначають, «що поняття «етична компетентність» неоднозначне, оскільки вона, у свою чергу, відноситься до знань та вмінь, пов'язаних 3 етикою, яку спеціаліст мобілізує під час своїх стосунків 3 іншими людьми» [28].

Це у свою чергу передбачає формування двох складових (компетенцій) етичної компетентності - практичне судження (розмірковування) та діалог, або комунікативна діяльність, метою якої $€$ спільне розв'язання етичних дилем. Практичне судження та діалог доповнюються етичною чутливістю, об'єктивним ставленням та нормативною базою професійної етики» [28].

Британський дослідник
А. Фрідмен пише, «що етична компетентність $€$ здатністю спеціаліста виконувати свою професійну діяльність згідно 3 моральним кодексом поведінки. Як правило, це означає дії, які базуються на етичних принципах: що правильно i що неправильно 3 огляду на потреби клієнта. А. Фрідмен також підкреслює, що етична компетентність $€$ тим елементом професійної компетентності, який необхідно включати до профресійної підготовки спеціаліста» [25].

Т. Брітинг [23] зазначає, «що для розуміння етичної компетентності треба розглядати ії як невербальне знання, яке не піддається кодифікації або словесному вираженню i здобувається через досвід та навчання». А. Т. Хоглунд робить висновок, «що етична компетентність - це не лише невербальне знання. Вона також не $є$ теоретичним знанням. Оскільки невербальне знання не можна уявляти, то потрібен когнітивний процес, який забезпечує словесне вираження та усвідомлення етичних дилем та способів їхнього розв'язання або критичного аналізу дій» [26].

Отже, беручи до уваги викладені
вище положення, етичну компетентність ми визначатимемо як здатність діяти згідно із особистим моральним кодексом та професійною відповідальністю.

«Етична компетентність завжди постає у трьох психологічних вимірах - це моральне сприйняття, моральне судження і моральна поведінка. Вона включає якості, що базуються на системі загальних цінностей» [27].

Проаналізувавши науковий дискурс деяких етикознавців, ми можемо зробити такі важливі для нашого дослідження висновки. Поперше, сутність етичної компетентності у найзагальнішому

HUMANITARIAN STUDIOS: PEDAGOGICS, PSYCHOLOGY, PHILOSOPHY Vol 12(4) 2021

(C) Лашкул В. А. , Тимофєєв В. А. 
вигляді складають такі явища, як:

- знання про етичні норми поведінки;

- готовність брати на себе обов'язок та відповідальність;

- вміння розв'язувати етичні дилеми;

- моральне судження.

По-друге, ми згодні з поглядами науковців, що етична компетентність передбачає наявність сукупності психологічно-особистісних якостей: раціональність, емоційність, проникливість, інтуїція.

На основі осмислення наведених вище точок зору сфрормулюємо розуміння феномену етичної компетентності у ракурсі інтересу нашого дослідження. Етична компетентність перекладача - це характеристика суб'єкта перекладацької діяльності, яка визначається наявністю етичних професійно важливих якостей, а також сукупності професійних знань про етичні поняття та норми поведінки й вмінь свідомого застосування їх у перекладацькій практиці 3 метою розв'язання етичних проблем. Процес дотримання етичних норм та розв'язання складних етичних ситуацій під час професійної перекладацької діяльності ми будемо називати професійно-етичною діяльністю.

Висновки. Аналіз фрілософрської та психолого-педагогічної літератури дозволяє нам зробити такі висновки щодо сутності етичного компоненту професійної діяльності перекладача.

По-перше, професія перекладача виконує важливу суспільну функцію. Перекладач у своїй професійній діяльності керується двома мотивами, які мають суто морально-етичний характер: внутрішнім, який спирається на моральну свідомість особистості, та зовнішнім, який базується на силі профресійного кодексу спеціаліста.

По-друге, вивчення компонентів профресійної компетентності перекладача вивело нас на системоутворюючий характер особистісного компоненту, який, у свою чергу, розпадається на дві складові, одна з якої відноситься до морально-етичної сфрери спеціаліста.

По-третє, розгляд досліджень у галузі професійної компетентності перекладача показав не вивченість аналізованої проблеми, але вказав на важливість ії розв'язання для забезпечення належного рівня професійної діяльності перекладача.

По-четверте,

ґрунтовний

компонентний аналіз професійної компетентності спеціаліста дозволив нам визначити внутрішню структуру етичної компетентності, яка складатиметься із знань, умінь, навичок та особистісної характеристики, тобто тих персональних якостей, необхідних для забезпечення цієї компетентності.

Перераховані вище положення дають нам обґрунтовану підставу для виділення етичної складової професійної діяльності перекладача в самостійну значущу компетентність, необхідну для успішного виконання спеціалістом своїх профресійних обов'язків та задоволення суспільних потреб.

\section{Список використаних джерел}

1. Балашов Л.Е. Философия. Москва: ИТК Дашков и К, 2003. 502 с.

2. Балл Г.О. Духовність профресіонала і педагогічне сприяння іiї становленню (орієнтири психологічного аналізу) // Професійна освіта: Педагогіка і психологія: Україно-польський підручник. ІІ ч. Київ: Чеснотохов, 2000. с. 217-231.

3. Баркасі В.В. Формування професійної компетентності в майбутніх учителів іноземних мов : автореф. дис. ... канд. пед. наук : 13.00.04. Одеса, 2004. 20 с

4. Бархударов Л.С. Язык и перевод. Вопросы общей и частной теории перевода. М.: Международные отношения, 1975. 240 с.

HUMANITARIAN STUDIOS: PEDAGOGICS, PSYCHOLOGY, PHILOSOPHY Vol 12(4) 2021

(C) Лашкул В. А. , Тимофєєв В. А. 
5. Брандес М.П. Стиль и перевод. М.: «Высшая школа», 1988. $126 \mathrm{c}$.

6. Виноградов В.С. Введение в переводоведение (общие и лексические вопросы). М.: Институт общего среднего образования РАО, 2001. 224 c.

7. Вознюк Н.М. Етико-педагогічні основи формування особистості : навч. посіб. Київ: Центр навчальної літератури, 2005. 196 с.

8. Дворецкий И.Х. Латинскорусский словарь. 7-е изд., стереотип. Москва: Русский язык, 2002. 846 с.

9. Зязюн І. А., Крамущенко Л. В., Кривонос І. Ф., та ін. ; за ред. І. А. Зязюн. Педагогічна майстерність [Електронний ресурс]. Режим доступу: http://www.twirpx.com/file/147648.

10. Закон України «Про освіту» [Електронний ресурс]. Режим доступу: http://zakon1.rada.gov.ua/laws/show/106 $0-12$.

11. Кунч 3.Й. Універсальний словник української мови. Тернопіль: Навчальна книга - Богдан, 2005. 848 с.

12. Латышев Л.К., Семенов А.Л. .Перевод: Теория, практика и методика преподавания: Учебник для студ. перевод. фрак. высш. учеб. Заведений. М.: Издательский центр «Академия», 2005. 192 с.

13. Лозовий В.О., Панов М.І., Стасевська О.А. та ін.; за ред. В.О. Лозового. Етика: навч. посіб. Київ: Юрінком Інтер, 2005. 224 с.

14. Мирам Г.Э. Переводные картинки. Профессия переводчик. К.: Ника-Центр, Эльга, 2001. 336 с.

15. Петренко К.П., Чужакин А.П. Мир перевода. 4. Аудиокурс / 2-е изд. М.: Р. Валент, 2001. 40 с.

16. Петренко Н.М. Вступ до перекладознавства. Дніпропетр. ун-т економіки і права. Каф. англ. фрілол. та пер. Дніпропетровськ. 2002. 139с.

17. Сухомлинський B.О. Проблеми виховання всебічно розвиненої особистості // Вибр. твори : в 5 т. Київ : Рад. шк., 1976. Т. 1. 654 с.
18. Федоров А.В. Основы общей теории перевода (лингвистические проблемы). СПб: Филологический фракультет СпбГУ, 2002. 416 с.

19. Чужакин А.П. Палажченко П.Р. Мир перевода - 1. Introduction to Interpreting XXI. Протокол, поиск работы, корпоративная культура, 6-е изд. Доп / М.: «Р. Валент», 2004. 224 с.

20. Ширяев А.Ф. Синхронный перевод. Деятельность синхронного переводчика и методика преподавания синхронного перевода. М.: Воениздат, 1979. 183 с.

21. Ягупов В. В. Педагогіка навч. посіб.. Київ: Либідь, 2002. 560 с. 22. Bowman J., Berman E.M., Wesy J.P., Bonzcek S.J. (1998). The professional edge. Washington D. C: International City: County Management Association, 159-164.

23. Brytting T. (2001). Att vara som Gud? - Moralisk kompetens i arbetslivet [To be like God? - Moral Competence in Work Life]. Malmo: Liber, $215 \mathrm{p}$.

24. Cheetham G., Chivers G. (1996). Towards a holistic model of professional competence // Journal of European Industrial Training. 20(5)., 2030.

25. Friedman A. (2007). Ethical Competence and Professional Associations. London: PARN, 112.

26. Hoglung AT. (2005). Ingo latta val. Om riktlinjer och etisk kompetens vid prioriteringar i varden. En studie i empirisk etik. [No easy choices. On guidelines and ethical competence in priority setting in health care. A study in empirical ethics] // Uppsala Studies in Faiths and Ideologies. Acta Universitatis Upsaliensis, Uppsala, N 15., 112-121.

27. Jormsri P., Kunaviktikul W., Ketefians A. (2005). Moral competence in nursing practice. Nursing Ethics. Chaowalit. N 12(6),. 582-594.

28. Patenaude J. (2016). Le dialogue comme compétence éthique: Thèse de doctorat en philosophie. [Dialogue so as compétence ethics:

HUMANITARIAN STUDIOS: PEDAGOGICS, PSYCHOLOGY, PHILOSOPHY Vol 12(4) 2021

(C) Лашкул В. А. , Тимофєєв В. А. 
thesis from a doctorate in philosophy]. Québec, 324

\section{References}

1. Balashov L. E. Filosofiya [Philosophy]. Moscow: ITK Dashkov i K, 2003. $502 \mathrm{~s}$.

2. Ball H.O. Dukhovnist profesionala i pedahohichne spryiannia yii stanovlenniu (oriientyry psykholohichnoho analizu) // Profesiina osvita: Pedahohika i psykholohiia: Ukraino-polskyi pidruchnyk. II ch [Spirituality of a professional and pedagogical assistance to its formation (guidelines of psychological analysis) // Professional education: Pedagogy and psychology: Ukrainian-Polish textbook. Part II.]. Kyiv: Chesnotokhov, 2000. s. 217-231.

3. Barkasi V.V. Formuvannia profesiinoi kompetentnosti $v$ maibutnikh uchyteliv inozemnykh mov. [Formation of professional competence in future foreign language teachers]: avtoref. dys. ... kand. ped. nauk : 13.00.04. Odesa, 2004. $20 \mathrm{~s}$.

4. Barkhudarov L.S. Yazyk i perevod. Voprosy obshchey i chastnoy teorii perevoda [Language and translation. Questions of general and particular theory of translation]. Moscow: Mezhdunarodnyye otnosheniya. 1975. $240 \mathrm{~s}$.

5. Brandes M.P. Stil i perevod [Style and translation]. Moscow: «Vysshaya shkola». 1988. $126 \mathrm{~s}$.

6. Vinogradov V.S. Vvedeniye $v$ perevodovedeniye (obshchiye i leksicheskiye voprosy) [Introduction to translation studies (general and lexical issues)]. Moscow: Institut obshchego srednego obrazovaniya RAO. 2001. 224 s.

7. Vozniuk N.M. Etykopedahohichni osnovy formuvannia osobystosti : navch. Posib [Ethical and pedagogical bases of personality formation: textbook]. Kyiv: Tsentr navchalnoi literatury, 2005. $196 \mathrm{~s}$.

8. Dvoretskiy I.Kh. Latinskorusskiy slovar [Latin-Russian dictionary]. 7-e izd.. stereotip Moscow: Russkiy yazyk. 2002. $846 \mathrm{~s}$.

9. Ziaziun I. A., Kramushchenko L. V., Kryvonos I. F., ta in. ; za red. I. A. Ziaziun. Pedahohichna maisternist [Pedagogical skills]. [Elektronnyi resurs]. Rezhym dostupu: http://www.twirpx.com/file/147648.

10. Zakon Ukrainy "Pro osvitu" [Law of Ukraine "On Education"]. [Elektronnyi resurs]. Rezhym dostupu: http://zakon1.rada.gov.ua/laws/show/106 0-12.

11. Kunch Z.I. Universalnyi slovnyk ukrainskoi movy [Universal dictionary of the Ukrainian language]. Ternopil: Navchalna knyha - Bohdan, 2005. $848 \mathrm{~s}$.

12. Latyshev L.K.. Semenov A.L. .Perevod: Teoriya. praktika i metodika prepodavaniya: Uchebnik dlya stud. perevod. fak. vyssh. ucheb. Zavedeniy [Translation: Theory, practice and teaching methods: A textbook for students of translation. fac. of high schools]. Moscow: Izdatelskiy tsentr «Akademiya». 2005. $192 \mathrm{~s}$.

13. Lozovyi V.O., Panov M.I., Stasevska O.A. ta in.; za red. V.O. Lozovoho. Etyka: navch. posib [Ethics: textbook]. Kyiv: Yurinkom Inter, 2005. $224 \mathrm{~s}$

14. Miram G.E. Perevodnyye kartinki. Professiya perevodchik [Transfer pictures. Profession translator]. Kyiv: Nika-Tsentr. Elga. 2001. 336 s

15. Petrenko K.P.. Chuzhakin A.P. Mir perevoda [The world of translation]. 4. Audiokurs / 2-e izd. Moscow: R. Valent. 2001. $40 \mathrm{~s}$.

16. Petrenko N.M. Vstup do perekladoznavstva [Introduction to translation studies]. Dnipropetr. un-t ekonomiky i prava. Kaf. anhl. filol. ta per. Dnipropetrovsk. 2002. 139s.

17. Sukhomlynskyi V.O. Problemy vykhovannia vsebichno rozvynenoi osobystosti // Vybr. tvory : v $5 \mathrm{t}$. [Problems of education of a comprehensively developed personality]. Kyiv : Rad. shk., 1976. T. 1. 654 s. 
18. Fedorov A.V. Osnovy obshchey teorii perevoda (lingvisticheskiye problemy) [Fundamentals of general translation theory (linguistic problems)]. SPb: Filologicheskiy fakultet SpbGU. 2002. $416 \mathrm{~s}$.

19. Chuzhakin A.P. Palazhchenko P.R. Mir perevoda [The world of translation]. - 1. Introduction to Interpreting XXI. Protokol. poisk raboty. korporativnaya kultura. 6-e izd. Dop / Moscow: «R. Valent». 2004. 224 s.

20. Shiryayev A.F. Sinkhronnyy perevod. Deyatelnost sinkhronnogo perevodchika i metodika prepodavaniya sinkhronnogo perevoda [Simultaneous translation. Activity of the simultaneous interpreter and methods of teaching simultaneous translation]. Moscow: Voyenizdat. 1979. $183 \mathrm{~s}$.

21. Yahupov V. V. Pedahohika : navch. Posib. [Pedagogy: textbook]. Kyiv: Lybid, 2002. $560 \mathrm{~s}$.

22. Bowman J., Berman E.M., Wesy J.P., Bonzcek S.J. (1998). The professional edge. Washington D. C: International City: County Management Association, 159-164.

23. Brytting T. (2001). Att vara som Gud? - Moralisk kompetens i arbetslivet [To be like God? - Moral Competence in Work Life]. Malmo: Liber, $215 \mathrm{p}$.

24. Cheetham G., Chivers G. (1996). Towards a holistic model of professional competence // Journal of European Industrial Training. 20(5)., 2030.

25. Friedman A. (2007). Ethical Competence and Professional Associations. London: PARN, 112.

26. Hoglung AT. (2005). Ingo latta val. Om riktlinjer och etisk kompetens vid prioriteringar i varden. En studie i empirisk etik. [No easy choices. On guidelines and ethical competence in priority setting in health care. A study in empirical ethics] // Uppsala Studies in Faiths and Ideologies. Acta Universitatis Upsaliensis, Uppsala, N 15., 112-121.

27. Jormsri P., Kunaviktikul W., Ketefians A. (2005). Moral competence in nursing practice. Nursing Ethics. Chaowalit. N 12(6),. 582-594.

28. Patenaude J. (2016). Le dialogue comme compétence éthique: Thèse de doctorat en philosophie. [Dialogue so as compétence ethics: thesis from a doctorate in philosophy]. Québec, 324.

\section{THE ESSENCE ANALYSIS OF ETHICAL TRANSLATOR'S COMPETENCE Lashkul V. A., Timofeev V. A.}

Abstract. In this article the authors reveal the essence of the phenomenon of ethical competence of the future translator, because the challenges of nowadays require the approval of new conceptual trends related to the humanization of education. These tendencies become especially relevant in the humanities and pedagogical education, especially in philology. Modern higher education should not aim only at forming the necessary amount of professional knowledge, skills and abilities of the future philologisttranslator or interpreter. It is required nowadays that the instrumental sphere of the personality of the graduate of the Faculty of Philology is closely combined with the development of motivational and value sphere, moral and ethical qualities, which in the synthesis provides a thorough professional and ethical training. The purpose of research is to analyze the essence of the phenomenon of ethical competence of the future translator, because the success of the future specialist - translator, his formation as a professional directly depends on the level of his professional and ethical training. In view of this, the realities of today require the intensification of pedagogical research aimed at studying the processes of formation and development of ethical competence in future translators. Results of research. Analysis of philosophical, psychological and pedagogical literature allows us to draw the following conclusions about the essence of the ethical 
component of the professional activity of a translator. First, the profession of translator performs an important social function. The translator in his professional activity is guided by two motives that have a purely moral and ethical character: internal, which is based on the moral consciousness of the individual, and external, which is based on the strength of the professional code of the specialist. Secondly, the study of the components of the professional competence of the translator led us to the system-forming nature of the personal component, which, in turn, breaks down into two components, one of which relates to the moral and ethical sphere of the specialist. Third, the review of research in the field of professional competence of a translator showed the lack of study of the analyzed problem, but pointed out the importance of its solution to ensure the appropriate level of professional activity of the translator. Fourth, a thorough component analysis of the professional competence of a specialist allowed us to determine the internal structure of ethical competence, which will consist of knowledge, skills, abilities and personal characteristics, i.e. those personal qualities necessary to ensure this competence. The above principles give us a reasonable basis for allocating the ethical component of the professional activity of a translator into an independent significant competence necessary for the successful performance of a professional's professional duties and meeting public needs.

Keywords: profession, translation, competence, competency, philology, ethics, morality, competence approach, education. 